\title{
Teaching Architectural History in Turkey and Greece: The Burden of the Mosque and the Temple
}

\author{
G ÜLS ÜM B AY D AR
}

Bilkent University, Ankara

Turkey and Greece occupy very different positions in relation to the standardized canon of architectural history. While ancient Greece provides the foundation of the monumental classical tradition of the West, Turkey's Ottoman empire is relegated to a marginalized position having no impact on the West. This fact is most apparent in Sir Banister Fletcher's A History of Architecture on the Comparative Method for the Student, Craftsman and Amateur, the earliest survey of architecture that included regions outside the West. ${ }^{1}$ Fletcher's famous frontispiece, Tree of Architecture, has a solid upright trunk that is inscribed with the names of European styles. Greek architecture appears first on the trunk. Non-Western stylesPersian, Mexican, Egyptian, Assyrian, Indian, Chinese, and Japanese styles-branch out from the trunk and do not grow beyond the seventh-century mark. Ottoman architecture does not even appear on Fletcher's diagram.

Despite their different historical impacts on the canon, Turkey and Greece shared a history under the Ottoman empire for three centuries until 1833, when Greece became an independent nation state. Interestingly, the Greek lands lost their privileged rank in the historiography of Ottoman architecture, which is centered on the monuments of the capital city of Istanbul. ${ }^{2}$ To my knowledge, the first survey of world architecture that includes a significant section on Ottoman architecture is Spiro Kostof's A History of Architecture: Settings and Rituals, which provides a comparative perspective on Venice and Istanbul. ${ }^{3}$ The postindependence architectures of Turkey and Greece, by contrast, have never been included in the grand narrative of architectural history. Even as separate fields of specialization, they have attracted attention outside their native borders only recently.

In preparing this text, my primary question has been: To what extent do the roles of Turkey and Greece in relation to the canon affect the teaching of architectural history in those countries today? As details of the architectural history curricula show, issues of national identity and modernization result in striking similarities between the approaches used in Turkey and Greece.

\section{The Institutional Setting}

In both Ottoman Turkey and Greece, architectural education was institutionalized in the nineteenth century. The earliest architecture departments in the Ottoman empire were in Istanbul. They were based on the engineering tradition and their curricula were technically oriented. The first department was founded in 1847 after the reorganization of the Royal School of Military Engineering, which had been founded in 1795. It offered courses in drawing, shipbuilding, construction of roads, bridges, and canals, topography, physics, chemistry, dynamics, and French and Western civilization. ${ }^{4}$ The second was the Civil Service School of Engineering, which incorporated a sufficiently broad range of courses that graduates could choose architecture as their field of expertise. An independent architecture department was founded in 1937 based on the German model of the technical school of higher education. The school's name was changed in 1944 to Istanbul Technical University, and today it has one of the largest architecture departments in the country, with a strong architectural history curriculum.

The third architecture school, established under the School of Fine Arts in 1883, was based on the Beaux-Arts model and was the first to include art history in its curriculum. ${ }^{5}$ History of architecture was included in a course called "Science of Architecture," which covered the Western world from antiquity to the Renaissance and Islamic civilization. It consisted of the study of individual components of historical buildings and was directly related to the design curriculum. In 1937, the school was renamed the Academy of Fine Arts, and it became the first modernist institution of architectural education in Turkey after the founding of the Turkish Republic in 1923. The cultural modernization project of the new republic was intricately integrated with architectural modernization. This phenomenon had a significant impact on architectural education, as explained below.

In Greece, architectural education was first introduced at the Technical School, which was founded in $1836 .{ }^{6}$ The founding decree mentioned the importance of architectural education, considering "the influence which architecture 
has on political life in general." 7 Until the 1860s, architecture courses were taught as part of the curriculum of the School of Civil Engineering. In the following years, gradual changes included a new emphasis on the classical orders and Renaissance morphology; the intention was to aid architectural design rather than to encourage intellectual growth. An independent school of architecture within the Technical School was established in 1917. The curriculum was, naturally, influenced by the school's practical orientation, as well as by contemporary German and Viennese programs and the Beaux-Arts tradition. Courses included "Building Technology," "Plastic Arts," "Urban Planning," "Painting," and "Architectural Form and Orders." Modernist interests in advanced technical knowledge and functionalism were integrated into the offerings in the late 1940s. It remained the sole institution for architectural education until the late 1950s, when Greece's second school of architecture was founded, in Thessaloniki. After administrative changes in the 1970s, the architecture school in Athens became part of the National Technical University in that city, which is now considered "a pioneer in the higher education of Greek architects."

There are striking similarities between the beginnings of architectural education in Turkey and Greece, and they have ongoing repercussions today. First, in both cases there is a marked divide between architecture as engineering and architecture as art. Second, both the Academy of Fine Arts in Istanbul and the School of Architecture in Athens embraced modernism to reform their Beaux-Arts-influenced programs. As such, their histories parallel many other Western curricula in Europe and North America. However, the most significant likeness between the Turkish and Greek cases is the integration of educational concerns with nationalist sentiments and a strong emphasis on regional traditions. From its early days, the Ottoman curriculum focused on Islamic civilization. Architectural and cultural modernization were inseparable in modern Turkey, and architecture and political life were inextricably linked in Greece. These are significant points, since nationalist sentiments, concern for regional traditions, and interest in developments in Western architecture have played a fundamental role in determining the present structure of architectural history curricula in both countries.

Today twenty-six institutions offer architectural education in Turkey, and six in Greece. In Turkey, two new major schools of architecture were established in 1942 and 1956. The first was founded under the aegis of Istanbul's Yildiz Technical University, which had developed from a technical school based on the model of the French École de Conducteur. The second was part of Ankara's Middle
East Technical University, which was based on the North American model and offers education in English. In Greece, in addition to the two schools in Athens and Thessaloniki, three new institutions were established in the 1990s, at the University of Thessalia, Volos; the University of Patras; and the University of Thrace, Xanthi.

After the 1960s, with changes in Turkey's legal codes, private schools of architecture proliferated in the major cities. Today departments of architecture fall into three distinct categories: departments of major public universities with relatively generous resources, departments of wellfunded private universities, and those of public universities in the provinces with limited resources for curriculum development. The architectural history curricula largely reflect the status of the schools. Well-established public schools like Istanbul Technical University, Yıldız Technical University, and the Middle East Technical University offer a broad range of graduate and undergraduate courses. In the majority of the others, architectural history is limited to a four-semester survey. Although all universities in Greece are public, their architectural history curricula display considerable differences in the approach and variety of courses offered.

\section{Teaching the Canon}

The architectural history survey course is the standard component of most architectural programs, in which students are introduced to the canonical premises of the discipline. In the last three decades, some of the leading schools in the West have restructured their survey course in a conscious attempt to question the canon, that is, to challenge its Eurocentric premises, its emphasis on form and style, and its preoccupation with master architects. In Turkey and Greece, such critical approaches are mostly implemented outside the survey course. However, the most significant difference from the West is the remarkable emphasis on native histories. The history of Ottoman/Turkish architecture in Turkish schools and of Greek architecture in Greek schools is one of the largest components of the survey. Equal emphasis is placed on modern Western architecture in both countries, while other historical periods play a considerably less significant role. The length of the survey course ranges from two to five semesters depending on the breadth of the architectural history curriculum.

In the case of Turkey, one of the primary aims is to incorporate Ottoman/Turkish history into the chronological grand narrative of Western architecture. Therefore Seljuk and Ottoman architecture are often taught in conjunction with Western Renaissance, Mannerist, and 
Baroque periods. Modern Turkish architecture is included in the final semester of the sequence, which is otherwise dedicated to the post-Enlightenment West. The curriculum at the Middle East Technical University is typical, with a survey spanning three semesters. The first semester covers ancient and medieval history, the second focuses on early Islamic, Seljuk, and Ottoman styles and the Renaissance, Mannerist, and Baroque eras, and the last covers the Enlightenment to the present, with a section on "current debates in Western and Turkish architecture." In many other schools, Ottoman/Turkish architecture occupies an entire semester as a separate section of the survey. At the Istanbul Technical University, for example, the four-semester course is structured as follows: ancient and Byzantine architecture, Turkish architecture, European architecture, and contemporary architecture.

In Greece, there is less emphasis on contemporary Greek architecture than on the country's ancient past. This is hardly surprising, as ancient Greece plays such a significant role in Western historiography. It is a potent source for reinforcing a sense of cultural and architectural identity, and hence is heavily emphasized in architectural history curricula. At the National Technical University of Athens, for instance, the chronological survey is taught in five semesters. The first three cover prehistoric and early Greek, Mediterranean, Minoan, and Mycenaean architecture; Greek and Roman antiquity; and the Byzantine, Western medieval, and Ottoman periods. The last two focus on the Western world from the Renaissance to the 1950s. While in Turkey there is a deliberate attempt to incorporate Ottoman/Turkish architecture into the canon, in Greece pre-modern Greek architecture carries equal weight. A glorified past is an unmistakable ideological component of history teaching in both countries.

In both countries, the emphasis on Western and native architectural traditions is further manifested in student assignments and field trips that are organized either as part of the courses or as extracurricular activities. At the Middle East Technical University, a summer elective called "Architecture in Situ" consists of field trips to Anatolia and/or Europe. Depending on the program they choose, the students are exposed either to Seljuk and Ottoman settings or to selected examples from the Western canon. Their research and documentation are exhibited in the following fall semester for all members of the entire department to view. Istanbul Technical University organizes faculty-sponsored field trips to sites both within and outside Istanbul as part of the architectural history curriculum. Students thus receive broad exposure to different historical architectural cultures in Turkey, ranging from ancient Greek and Roman to those of the Ottoman empire. Greek programs are marked by similar efforts. Study trips to canonical examples of European modernism are a significant feature at the National Technical University of Athens. A recent tour called "Le Corbusier in Diagonalis" exposed students to Le Corbusier's major works from La Chaux de Fonds to Roquebrune-Cap Martin. In both Turkey and Greece, emphasis on local traditions and the Western canon is further marked by instances where students are required to construct models and make drawings of representative buildings.

Despite a predominantly conservative approach to the canon, in both Turkey and Greece there is scattered evidence that instructors are reconsidering the chronological sequence of the grand narrative within the survey course. For the most part, this shift is occurring in relatively young universities where there is no rooted tradition of teaching the canon. Istanbul Kültür University and the University of Thessaly, both founded in the 1990s, are exemplary in this respect. In the former, twentieth-century architecture is taught as an introductory course before the standard history. At Thessaly, students are introduced to the history of architecture from prehistory to the present in their first year. They then take two courses on the chronological development of Western architecture. At the Aristotle University of Thessaloniki, by contrast, the first-year curriculum includes both required and elective courses on the history of modern art and architecture. The priority of Western architecture over native histories remains unquestioned in both Turkish and Greek curricula. For both sides the aim is to set a curriculum that is on par with those of international architecture schools. ${ }^{9}$ Ironically, in both cases, non-Western architectural cultures remain largely outside the scope of history. Internationalist claims are limited to the inclusion of North American and Western European architectural traditions.

The centrality of the Western world in architectural historiography has further implications for the teaching of history in both Turkey and Greece. The global dominance of the English language has serious consequences in terms of the accessibility of scholarly publications for students educated in their native languages. Most students, especially at the undergraduate level, rely on translations of standard texts. Such important sources as Vitruvius's Ten Books on Arcbitecture and Leonardo Benevolo's Modern Arcbitecture are available in Turkish, and Kenneth Frampton's Modern Architecture and David Watkin's History of Western Architecture have been translated into Greek. In addition, native scholars in both countries have written standard architectural history textbooks. In Greece, the teaching is exclu- 
sively in Greek, but at the Middle East Technical University and all private universities in Turkey education is offered in English. However, for all but a privileged minority of students who have acquired language skills during their preuniversity years, language remains a major problem in architectural history education. In Turkish universities outside major cities like Ankara, Istanbul, and Izmir, students rely exclusively on lecture notes. Hence the background and approach of the individual instructor often becomes the sole determinant of the students' understanding of architectural history.

\section{History and Theory}

With few exceptions, the integration of architectural history and theory are mostly confined to upper-level elective and graduate courses in both Turkish and Greek programs. Although there are scattered examples where the standard history survey is called "History and Theory of Architecture," the content of the theoretical component varies tremendously, ranging from the history of theory to contemporary philosophy.

In Turkish universities, history and theory are generally kept separate. Such figures as Vitruvius and Leon Battista Alberti are mentioned in the survey courses without an indepth examination of their ideas. This is mostly explained by the lack of sufficient time in the curriculum, the presumed necessity of learning basic historical material before abstract theoretical principles, and students' lack of enthusiasm for extensive reading. However, in the majority of schools where the chronological survey covers contemporary Western architecture, students learn about such current philosophical notions as neorationalism, postmodernism, and deconstructivism. This exposure is primarily due to the efforts of individual instructors rather than explicitly stated curricular aims.

In general, the attempt to integrate history and theory is much more prominent in Greek curricula. At the National Technical University of Athens, the history of architectural theory is systematically linked to the history of architecture, particularly from the Renaissance to the present. The invention of theory in the Renaissance, the discovery of history and language during the Enlightenment, and the meaning of modern and current theoretical debates are addressed as part of the survey course. At the University of Thessaly, the combination of history and theory is stated as one of the fundamental premises of the curriculum. Theory enters the picture as design abstractions, whereby students are exposed to such notions as type, model, metaphor, analogy, and symbol. These terms form

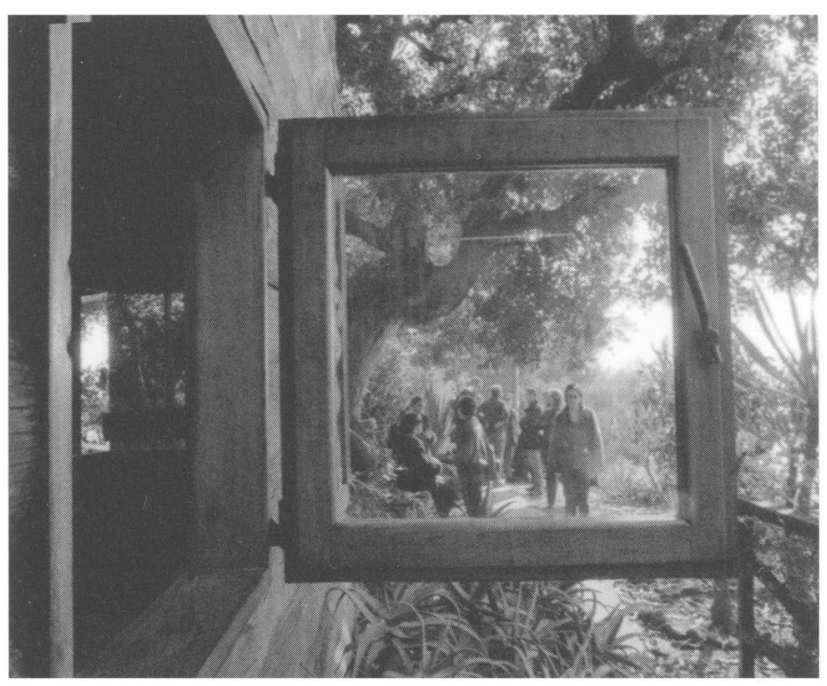

Figure 1 Students from the National Technical University of Athens at Le Corbusier's Cabanon at Cap Martin, France, during their field trip, "Le Corbusier in Diagonalis," 1999

the key elements of the vocabulary of the standard chronological survey.

In both Turkey and Greece, undergraduate students are occasionally presented with contemporary debates in separate theory courses. Examples of such courses are "Special Topics in Architectural Theory" and "Gender and Space" (National Technical University of Athens); "History of Architecture, 1945-2000: From Construction to Deconstruction" (Aristotle University of Thessaloniki); "Thinking, Reading, Writing on Architecture" (Middle East Technical University, Ankara); "Theories of Art and Architecture" (Istanbul Technical University); and "Contemporary Topics in Architecture” (Beykent University, Istanbul). The situation changes considerably in graduate programs, where a broad range of specialized courses that combine architectural history and theory is available.

In Turkey, the Middle East Technical University and Istanbul Technical University are the most prominent institutions with graduate programs in architectural history. That of the former is known for its theoretical focus and that of the latter for its emphasis on the history of Ottoman/Turkish architecture. Although the range of graduate courses varies each academic year, such offerings as "Theories of History" and "Cosmological Thought and Architecture in the Middle East" (Middle East Technical University) and "New Approaches in Ottoman Architectural History" (Istanbul Technical University) are exemplary in their combination of historical and theoretical interests. In the isolated case of Karadeniz Technical Uni- 


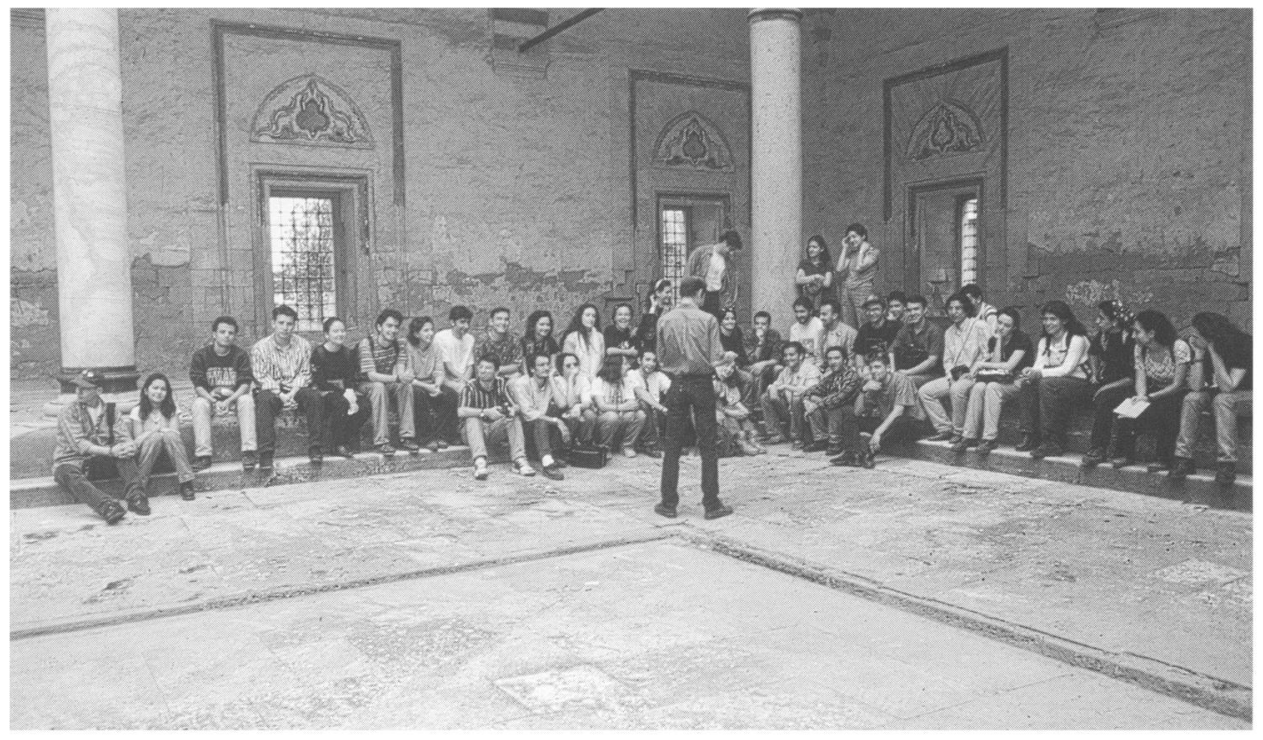

Figure 2 Students from the Istanbul Technical University at the Bayezid Mosque in Edirne during a field trip organized as part of their Turkish architecture course, 1997

versity, the history of architectural theory and contemporary theories are treated in two separate courses. At the National Technical University of Athens, in a unique interdepartmental postgraduate program in architecture and space planning, the history and theory of architecture is introduced as a separate field. It includes critical topics like the "modern" issue in Greek architecture, and philosophy in architectural theory and practice, which have historical as well as theoretical components.

To summarize, whereas history and theory are connected somewhat sporadically in the Turkish programs, they are self-consciously linked in the curricula of the leading Greek universities. In general, theory is incorporated in two ways: via the history of architectural movements and via the relationship between architecture and such contemporary theories as postmodernism, deconstructivism, and feminism. The first approach is typical of the survey courses. The second is more popular and is given considerable weight in elective and graduate courses. There are two possible reasons for the popularity of the latter. First, leading universities in both Turkey and Greece seek to create programs that are competitive internationally, especially with North America. Second, the proliferation of critical theoretical publications in the last few decades has had far-reaching effects in architecture schools. In addition to scholarly publications, the work of such well-publicized architects as Peter Eisenman, Rem Koolhaas, and Bernard Tschumi, who integrate theory into their design practice, has been highly influential. Contemporary theories are much more attractive to architecture students who may not find an immediate link between the history of architectural theory and the design studio.

\section{Teaching National/Native Histories}

If the emphasis on contemporary architecture in both Turkish and Greek curricula can be linked to the desire to be included on the international map, the reasons for the focus on native traditions are based on the will to assert a national architectural identity. This is not surprising, considering the strong histories of nationalism in both countries after their respective wars of independence. Moreover, in both cases, nationalist sentiments have been consistently interwoven with the desire for modernity. This phenomenon had profound architectural and urban implications, from the planning of the capital cities of Ankara and Athens to the stylistic manifestations of modernism and regionalism. Modern Turkish architectural historiography is the most telling example of the direct effect of nationalist ideologies in architecture, as it identifies three successive stylistic periods: the First National movement, Internationalism, and the Second National movement. ${ }^{10}$ Architectural history remains a critical field in which issues of national and cultural identity are deeply inscribed.

The situation has hardly changed in the present age of globalization. In the Istanbul Technical University curriculum, for example, the architectural heritage of the "Anatolian soil" is emphasized "to raise the students' consciousness about the civilizations that we inherit and are responsible for." ${ }^{11}$ A similar tone prevails at the National Technical University of Athens. According to the faculty there, "the main issue that differentiates a school of architecture in Athens from a school of architecture in Turkey or in France is Athens and Greece. Should there be any specialization, this should be Athens and Greece. We have the real buildings in 
situ, we have a lot of specialized professors and researchers, these buildings make our national identity, and so naturally we should encourage Greek studies." ${ }^{12}$ In other cases, especially in smaller universities in Turkey, such objectives are not always explicitly stated, as the curricula are adopted directly from leading universities.

There is a second reason besides nationalism for the emphasis on native histories in Turkish and Greek curricula, which is to include native architectural traditions in the Western canon. The idea is to show that native histories fit into a larger architectural narrative on equal footing with Western traditions. If nationalistic motivations are based on difference, such approaches are founded on the notion of sameness, that there is a single grand narrative of architecture in which every culture plays a part. At Istanbul Kültür University, for example, "Turkish/Islamic architecture is discussed within the general framework of the history of world architecture," as the aim is to place the former in a "general history of art and architecture." 13 A similar tone prevails at the University of Thessaly. There, teaching is based on an "ecumenical" approach "whereby local architectural traditions assume their particular meaning/efficacy in the broader context of the European civilization in its most generic definition." ${ }^{14}$ In fact, the nationalist and internationalist perspectives are two sides of the same coin: both are based on the desire to secure an architectural identity in relation to the canon. Critical topics of identity and nationalism rarely receive theoretical reflection.

Not surprisingly, therefore, the curricula in Turkish and Greek universities reflect a predominantly conservative approach to native histories. In Turkey, such specialized courses on Sinan, the classical age of Ottoman architecture, and architecture of nineteenth-century Istanbul emphasize form, style, and building technology. At best, the cultural and political context of the period is explained as the formative background of architectural developments. In Greece, specialized courses in ancient and modern Greek art and architecture are largely available. As in Turkey, a canonical approach predominates in such courses as "Greek Neoclassicism" and "Greek Art since 1945."

The well-established distinction between high style and vernacular persists in both countries. Native histories almost exclusively address monumental and symbolic buildings. The topic of the vernacular has conventionally received more architectural than historical emphasis. In vernacular studies, issues of typology, form, and construction dominate over historical change and historiography. Critical reflections on regionalism and the study of the vernacular are largely absent from the curricula of Turkish and Greek programs, and courses on vernacular architecture are scarce.

\section{The Relationship between Art, Architecture, and Urban History}

Art history and urban history are included in most programs of Turkish and Greek universities. Undergraduate courses often combine art, urbanism, and architecture, although the main focus remains on architecture.

In Turkish schools, the history of the city is often treated in a separate course within the architecture programs. Art history, however, is readily integrated into the architecture survey course. Unlike Greece, where specialized art historical courses proliferate in architectural programs, such offerings are confined to art history departments in Turkey. This difference may be due to the lack of art history departments in Greece and a relatively weak interest in the field. ${ }^{15}$

In general, Greek schools adopt a more comprehensive approach, whereby history, theory, art, architecture, and urbanism are integrated in one program and often in a single course. At the National Technical University of Athens, history of architecture, history of art, and theory of architecture are unified under the umbrella of the design department. Urban and regional planning is a separate department within architecture. Recent curricular developments have included combined courses in design and urban planning. ${ }^{16}$ The department's five-part survey course, "History and Theory," provides a strikingly broad scope of artistic, architectural, and urban themes, which also include aspects of theoretical developments. Such an approach is present at other universities as well, although it is not always stated as curricular policy.

\section{New Approaches}

The past three decades have seen a growing interdisciplinary treatment of architectural history, in which issues of style and form are addressed in relation to social, cultural, and political contexts. Kostof's $A$ History of Arcbitecture is the most prominent textbook setting the tone for the survey courses in architectural history. Although the canonical emphasis on architectural form still dominates the majority of programs, the teaching of architectural history is marked by an emerging awareness of cultural context. As the contributors to this article from both Turkey and Greece have attested, this trend is due primarily to singular efforts by individual instructors. Whereas young universities are more receptive to the interdisciplinary approach, those with longestablished traditions tend to be more conservative.

In a few Turkish and Greek programs, separate courses on sociology and culture are included in the architectural curricula. Such topics as the philosophy and sociology of 
art at the architectural history program of Istanbul Technical University, and sociology at the National Technical University of Athens, recast the interpretation of space and the arts. Students are exposed to a variety of research methods and techniques and broaden the scope of their architectural knowledge as it relates to other fields.

A recent and remarkable generation gap has had a serious impact on a number of Turkish and Greek architectural history programs. The newer generation of historians with Ph.D. degrees from North American, French, and British institutions has introduced alternative critical perspectives to their programs. ${ }^{17}$ These scholars are highly aware of current interdisciplinary historical and theoretical debates, and their approach to architectural history is informed by contemporary postcolonial, poststructuralist, psychoanalytical, and feminist theories. The Middle East Technical University in Ankara and the National Technical University of Athens are the most prominent examples. In these institutions, current publications are easily available, academic staff are globally mobile, and internationally known scholars are invited to lecture and participate in conferences. Faculty and students at these schools are equipped with the necessary level of language skills to engage intensively with contemporary historiographical debates. Until recently, interest in the architectural histories of post-antique Greece and post-Ottoman Turkey has mostly been confined to area specialists and native scholars. But in the past decade, increasing numbers of Turkish and Greek scholars, most trained exclusively or at least partly in European and North American universities, have revised their native historiographical traditions. Moreover, their work has been available to not only Turkish- and Greek- but also English-speaking audiences. Eleni Bastéa's study of modern Athens and Sibel Bozdoğan's work on Turkish architectural culture in the early Republic are two of the most recent and prominent examples. ${ }^{18}$ The long-term effects of such scholarship on the teaching of architectural history around the globe are yet to be seen.

\section{Appendix}

The countries covered in this study are Turkey and Greece.

Respondents

Turkey

Aygül Ağır, Research Assistant, Istanbul Technical University

Berrin Akgün, Research Assistant, Balıkesir University

Leyla Baydar, Associate Professor, Department of Architecture, Gazi University, Ankara

İhsan Bilgin, Associate Professor, Yıldız Technical University, Istanbul

Sedat Emir, Assistant Professor, Faculty of Architecture, Dokuz Eylül University, Izmir

Elvan Ergut, Assistant Professor, Department of Architecture, Middle East Technical University, Ankara

Orhan Hacıhasanoğlu, Professor, Faculty of Architecture, Istanbul Technical University

Nuray Özaslan, Department of Architecture, Anadolu University, Eskişehir

Güven Arif Sargin, Assistant Professor, Department of Architecture, Middle East Technical University, Ankara

Ege Uluca Tümer, Research Assistant, Department of Architecture, Istanbul Kültür University

Gülay Keleş Usta, Karadeniz Technical University, Trabzon

Sercan Yildırım, Associate Professor, Department of Architecture, Istanbul Kültür University

Greece

Yorgos Karadedos, Associate Professor, School of Architecture, Aristotle University of Thessaloniki

Vilma Hastaoglou-Martinidis, Associate Professor, Department of Urban and Regional Planning, Aristotle University of Thessaloniki

Philippos Oraiopoulos, Associate Professor, Faculty of Architecture, University of Thessalia, Thessaloniki

Vassiliki Petridou, Associate Professor, Department of Architecture, University of Patras

Panayotis Tournikiotis, Assistant Professor, School of Architecture, National Technical University of Athens

Web Sites

Turkey

Anadolu University, www.anadolu.edu.tr

Beykent University, www.beyu.edu.tr

Dokuz Eylül University, www.deu.edu.tr

Istanbul Kültür University, www.iku.edu.tr

Istanbul Technical University, www.itu.edu.tr

Izmir Institute of Technology, www.iyte.edu.tr

Karadeniz Technical University, www.ktu.edu.tr

Middle East Technical University, www.metu.edu.tr

Yildiz Technical University, www.yildiz.edu.tr

Greece

National Technical University of Athens, www.ntua.gr

University of Patras, www.upatras.gr

University of Thrace, www.duth.gr 


\section{Notes}

I would like to thank all the respondents who provided information for this text, especially Panayotis Tournikiotis for his valuable knowledge of the scope of architectural history education in Greece and his patience with my seemingly endless questions.

1. Sir Banister Fletcher, A History of Arcbitecture on the Comparative Method for the Student, Craftsman and Amateur, 16th ed. (London, 1954). The regions outside the West were first introduced in the fourth edition of the book, in 1901.

2. Godfrey Goodwin's A History of Ottoman Arcbitecture (London, 1971) is a classic example to illustrate this point.

3. Spiro Kostof, A History of Architecture: Settings and Rituals (New York, 1985), 454-68.

4. Çağatay Uluçay and Enver Kartekin, Yüksek Mühendis Okulu (Higher school of engineering) (Istanbul 1958), 41.

5. Sanayi-i Nefise Mektebi Talimatname ve Ders Programlarn (The regulations and curriculum of the School of Fine Arts) (Istanbul, 1911), 12.

6. All historical information about architectural education in Greece comes from the excellent introduction in E. Varouchaki, ed., M. Hatzimichali, trans., Course Curriculum, National Technical University of Athens, School of Architecture, 2000-01 (Athens, 2000).

7. Ibid., 7.

8. Ibid., 5 .

9. This goal was stated by a number of respondents from Turkey and Greece: Aygül Ağır, e-mail correspondence with the author, 12 Feb. 2002; Nuray Özaslan, e-mail correspondence with the author, 8 Feb. 2002; and Philippos Oraiopoulos, correspondence with the author, 17 June 2002.

10. A typical account of this periodization can be found in Renata Holod and Ahmet Evin, eds., Modern Turkish Architecture (Philadelphia, 1984). An informative essay on the relationship between the ancient, vernacular, and modernist approaches in Greek architecture is Panayotis Tournikiotis "Greece," in R. Stephen Sennett, ed., Encyclopedia of Twentieth-Century Architecture, 3 vols. (Chicago, forthcoming in Apr. 2003).

11. Ağır, 12 Feb. 2002. Although Ağı's next statement clarifies that the issue is less about identity than a sense of belonging to a place, the boundary between the two is extremely tenuous.

12. Panayotis Tournikiotis, e-mail correspondence with the author, $26 \mathrm{Jan}$. 2001.

13. Ege Ulucatümer, e-mail correspondence with the author, 7 Feb. 2002. 14. Oraiopoulos, 17 June 2002.

15. Panayotis Tournikiotis, e-mail correspondence with the author, 25 July 2002.

16. Varouchaki, Course Curriculum, 17. The term "department" refers to a group of courses organized under a single unit.

17. While North American universities are more popular destinations for Turkish students, most Greek students attend French and British programs. Panayotis Tournikiotis, e-mail correspondence with the author, 12 Aug. 2002.

18. Eleni Bastéa, The Creation of Modern Athens: Planning the Myth (Cambridge, England, 2000), and Sibel Bozdoğan, Modernism and Nation Building: Turkish Architectural Culture in the Early Republic (Seattle, 2001).

\section{Illustration Credits}

Figure 1. Photograph by Dimitra Georgantopoulou, courtesy Panayotis Tournikiotis

Figure 2. Courtesy of Zeynep Kuban, Turgut Şaner, and Aygül Ağır 